\title{
Miranda
}

Revue pluridisciplinaire du monde anglophone /

Multidisciplinary peer-reviewed journal on the English-

speaking world

$20 \mid 2020$

Staging American Nights

\section{Will they, won't they? Dream sequences and virtual consummation in the series Moonlighting}

Shannon Wells-Lassagne

URL: http://journals.openedition.org/miranda/24852

DOI: 10.4000/miranda.24852

ISSN: 2108-6559

Publisher

Université Toulouse - Jean Jaurès

Electronic reference

Shannon Wells-Lassagne, "Will they, won't they? Dream sequences and virtual consummation in the series Moonlighting", Miranda [Online], 20 | 2020, Online since 24 March 2020, connection on 16 February 2021. URL: http://journals.openedition.org/miranda/24852 ; DOI: https://doi.org/10.4000/ miranda. 24852

This text was automatically generated on 16 February 2021

\section{(c) $(1)$}

Miranda is licensed under a Creative Commons Attribution-NonCommercial-NoDerivatives 4.0 International License. 


\title{
Will they, won't they? Dream sequences and virtual consummation in the series Moonlighting
}

\author{
Shannon Wells-Lassagne
}

\section{Introduction}

1 This article deals with a series that continues to impact the TV and film landscape today: Moonlighting, a fiction which appeared on American broadcast network ABC from 1985 to 1989, and which introduced Bruce Willis to the screen. The show dealt with a fashion model, Maddie Hayes (played by Cybill Shepherd), whose funds are embezzled by a fraudulent accountant and who finds one of her only remaining resources is the co-ownership of a detective agency, The Blue Moon (named for a shampoo for which she once modelled). Her partner at the agency is David Addison, aka Bruce Willis, who has a somewhat dissipated and cynical attitude toward the business, in marked contrast to Maddie's more uptight stance. From one week to the next the two leads deal with various absurdly complex cases (faking one's death is a common phenomenon in the world of Moonlighting, apparently), all while constantly bickering.

of course, the storyline is not really what is groundbreaking or innovative about the series: it was not necessarily the content, but the delivery, that made Moonlighting unique. While creator Glenn Gordon Caron suggested that he had initially been inspired by a performance of Taming of the Shrew that he had seen shortly before with Meryl Streep and Raul Julia (Caron), Cybill Shepherd, who plays lead Maddie Hayes, rightly remarked that the pilot was similar to screwball comedies Bringing up Baby and The Philadelphia Story (Caron), and the series luxuriated in witty repartee and quick banter; this may not seem revolutionary to viewers who have since experienced many an Aaron Sorkin monologue, but at the time, the idea of an hour-long series, a length that 
traditionally indicated a drama, indulging in quick-witted banter essentially left behind since classic Hollywood, was completely novel-its importance can perhaps be measured by the ubiquity of this mixture of comedy and drama, or dramedy, on the small screen today. J.P. Williams gives an apt description of the novelty of the series:

Moonlighting clearly exhibits the semantic features of television drama: serious subject matter dealing with incidents of sufficient magnitude that it arouses pity and fear; rounded, complex central characters who are neither thoroughly admirable nor despicable; textured lighting-both the hard telenoir and the diffused lighting accompanied by soft camera focus; multiple exterior and interior settings, single camera shooting on film. But the series combines the "serious" elements with the syntactic features of television comedy. These comedic features include a four-part narrative structure (consisting of the situation, complication, confusion, and resolution), the metatextual practices of verbal self-reflexivity, musical selfreflexivity, and intertextuality, repetition (i.e., the doubling, tripling, and compounding of the same action or incident until the repetition itself becomes humorous), witty repartee, hyperbolic coincidence, and a governing benevolent moral principle within which the violent, confused, often ironic dramas of good and evil, seriousness and silliness were played out (90).

3 Thus Moonlighting's invention of the dramedy is not simply a question of tone or genre; as this quote makes clear, comic or dramatic tone is created through character, aesthetics, narrative structure, as well as content. It is in its fusion of pertinent elements of comedy and drama that Moonlighting is truly innovative. Its creation of "dramedy" was a watershed moment in American television, though of course the series was also taking its cue from venerable genres of early sound cinema like the screwball comedy or the hard-boiled novel (particularly The Thin Man and its film adaptations) and translating them to television's changing structures and aesthetics, participating in what has been termed the second Golden Age of television (Thompson) ${ }^{1}$.

Beyond its generic innovations, its repeated use of reflexivity makes Moonlighting one of the first examples of postmodern television. The series was constantly breaking the fourth wall to have the characters refer to their fictional status (or the series as a series): thus Season 3 famously began with Cybill shepherd and Bruce Willis standing in front of a desk on the set, introducing themselves in character as "Maddie Hayes" and "David Addison", and then welcoming the audience to a new season of the show (3.1); David once joked that if he held Maddy any closer, they would all have to move to cable television (2.8); and indeed, the final episode of the series interrupts its case of the week to announce that the show is being cancelled by $\mathrm{ABC}$, and ends with David and Maddie running from one place to another trying to change the minds of television executives (5.13).

5 However, arguably what it's best known for is what they still refer to as "The Moonlighting effect". The series ultimately focuses on the romantic tension between the two leads, constantly sparring but seemingly drawn to one another. Though the "will they/won't they?" narrative has long been a staple of the silver screen, translating it into weekly episodes was more complicated-like its sitcom contemporary Cheers (NBC, 1982-1993), with a similarly mismatched couple (Sam and Diane), the writers struggled to maintain the central tension without creating undue frustration for the viewer. While David and Maddie continued to spar in "real/reel" life, the series offered relief from this frustration in the form of regular dream sequences where they consummated their relationship, either as themselves, or as other characters. Ultimately the show 
kept the characters apart until the penultimate episode of season 3 (a total of $38 \mathrm{TV}$ hours of romantic tension), only to have the popularity of the show go into sharp decline once the relationship was consummated. It is that fear that "consummation equals cancellation" that is referred to as "The Moonlighting effect".

6 My contention is that all of these elements-generic hybridity, postmodern reflexivity, and dramatic/romantic tension-coalesce in one of the series' hallmark tropes: the dream sequence. The show's use of the dream sequence therefore becomes a means of examining Moonlighting's concerns with thematic content (primarily the gender wars implicit in the massive arrival of women in the workplace of the 70s and 80s and postfeminist insistence on the ability of the modern woman to "have it all") as well as its structural, generic, and aesthetic concerns, expanding the possibilities of what television could do, and emphasizing its role as a worthy successor to the silver screen. Though Moonlighting was in many ways a show fraught with difficulties and imperfections $s^{3}$, it was also groundbreaking in both form and content for the small screen, and the way it staged its nights through repeated dream sequences is in many ways a crystallization of its innovations. Indeed, these dream sequences became a veritable hallmark of the show, to the extent that a season 4 episode had David hallucinating Maddie's face in the telephone she had strictly forbidden him from using to contact her (4.2). His response to phone-Maddie's reprimand as he gives in to temptation is indicative of the nature of the series: "You think I'd be used to these dream sequences by now."

Fig. 1

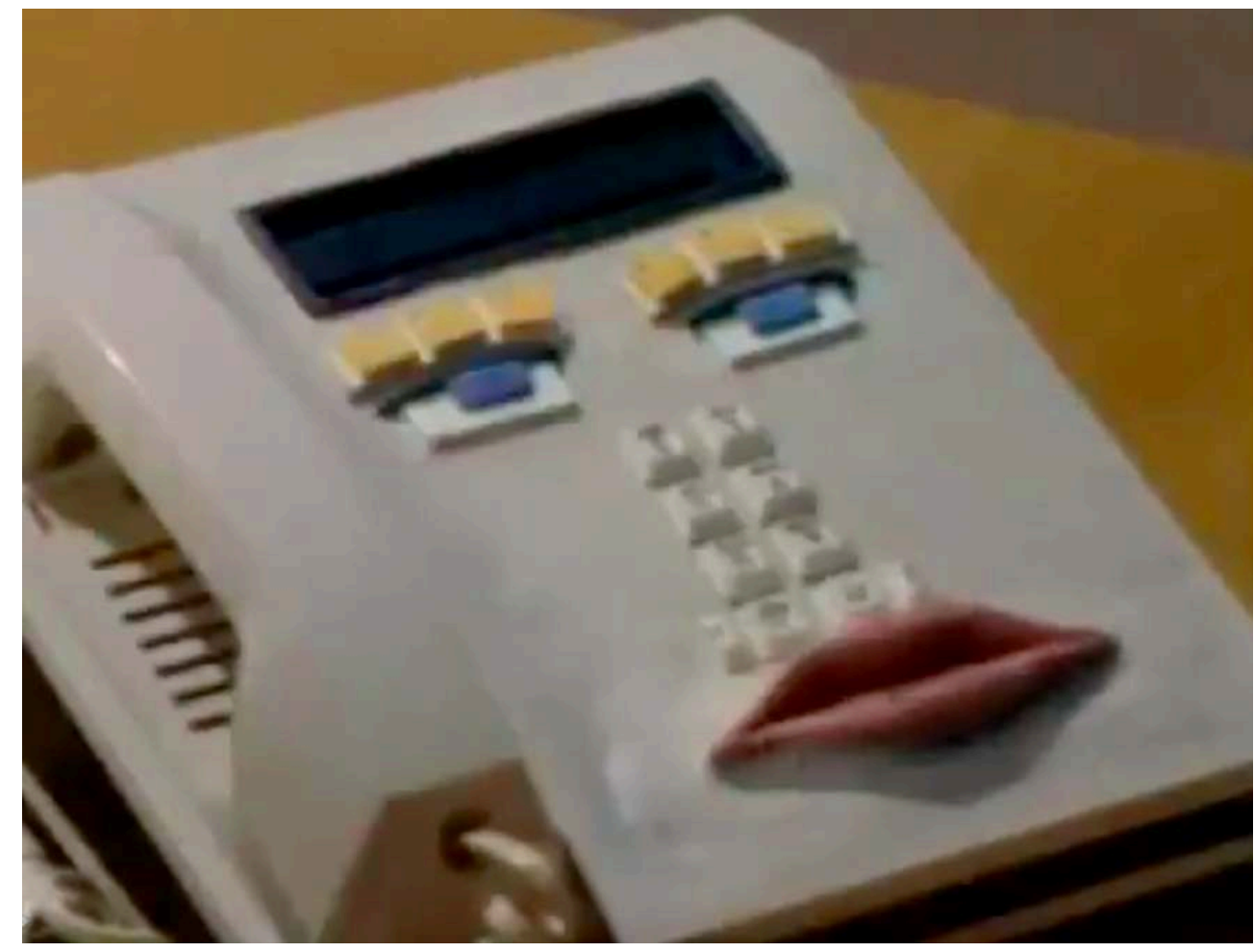

Dream sequences as Moonlighting's calling card (4.2)

7 The "habit" of incongruity-of using old film techniques (like Claymation) to new comic effect (though in an initially dramatic context)-is one that is consistent to the series. 
However, just as the show's titular "Moonlighting effect" suggests a "before" and "after" consummation (with a corresponding decrease in popularity and perhaps quality), so I hope to show how the dream sequence also evolves through the course of the series, offering a lens through which to view the changes to the fiction's conception of television and gender roles, its form and content.

Dream sequences are of course nothing new to screen fictions; indeed, more than one critic has suggested that dream sequences began with film itself, whether they cite Edwin S. Porter's The Life of an American Fireman (1903) or the better-known example of Buster Keaton's Sherlock Junior in 1924 (Hatchuel 16). Interestingly, at about the same time, writer and director René Clair suggested that film and dreams were linked:

The spectator's state of mind is not unlike that of a dreamer. The darkness of the hall, the enervating effect of music, the silent shadow gliding across the luminous screen-everything conspires to plunge us into a dreamlike state in which the suggestive power of the forms playing before us can become as imperious as the power of the images appearing in our veritable sleep. ("Reflections of the Cinema", qtd. Burkhead 7)

Even more contemporary filmmakers have acknowledged this association: Martin Scorsese, for example, admitted that his landmark film Taxi Driver was inspired by the idea that films induce a dream state, and coming out of a dark theater into the bright sunshine is akin to abruptly waking up (Bronfen 265).

Of course, the relationship between film and dream is not necessarily the same as the relationship between dream and dream sequence. As James Walters noted in his work on film,

[...] even from an early stage, cinema was committed to portraying a fantasy of the dream experience rather than providing an accurate account. [...] Thus, among the multitudinous dream sequences observable in narrative cinema, a great many present the dream as a stable, logical and discrete environment that possesses few of the inconsistencies, perplexities or banalities of real-life dreaming. In this sense, they function in the films as 'worlds' in their own right, contained within the wider fictional world of the film. The dreamer, most often, then functions as a character in that world, to the extent that we may even temporarily forget we are still watching their dream at all (46).

11 Walter's assertion that dream sequences have little to do with dreams, per se, and much to do with the story the film is telling makes clear that dream sequences balance content and medium, the story and the possibilities offered by film to tell it. The early examples of the dream sequence bear this contention out visually: in both Porter and Keaton's work, dreams are central to the story, but the characters' reveries mimic the imaginative possibilities of the new medium, something made concrete onscreen when narrative coherency demands that we see both dreamer and dreamed, using what were at the time innovative special effects to insist on the uniquely filmic nature of the sequence. 
Fig. 2 and 3
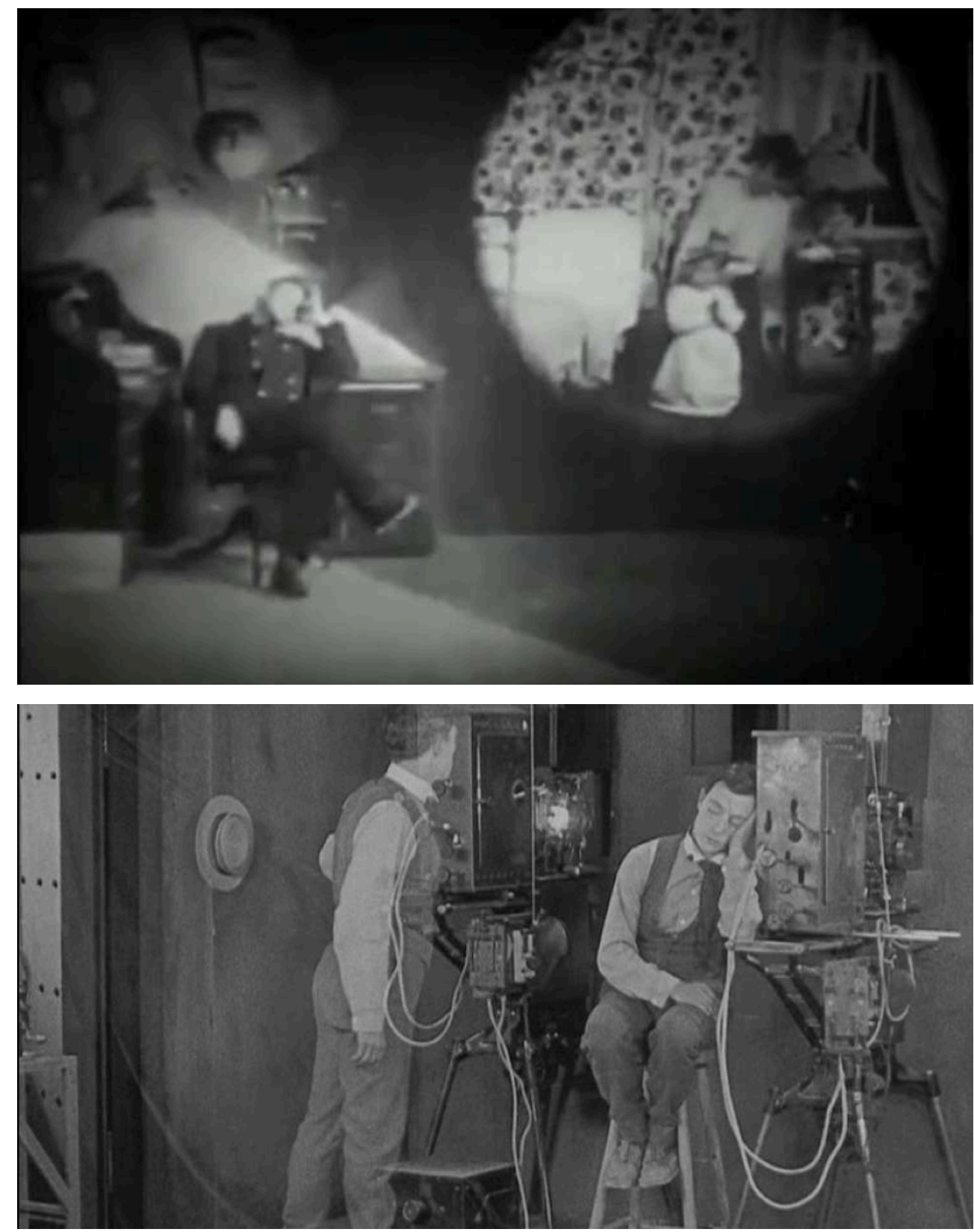

Edwin S. Porter and Buster Keaton: using dream sequences to tell a story-and highlight filmic status

12 Though these reflections deal with film, television may be even better suited to deal with and specialize in dream sequences, given the sheer breadth of narrative (over years and dozens of hours), combined with the technical and practical limitations of television before the boom of luxury cable shows (limited budget, limited sets and special effects, more or less permanent cast members), all of which combined to make character study one of television's strengths. As a means to represent the interiority of these characters, then, the dream sequence is uniquely suited to the small screen, and as Sarah Hatchuel suggests in her study on dreams in contemporary American television, can serve different functions in the fiction in which they appear:

Dreams can be dramatic twists or "might have beens"; they can offer narrative divergences; they can be the source of disorientation when they are clandestine- 
that is to say, when dreams are not announced as such; they can also explore extreme or taboo situations, where TV series become the locus for ethical and ideological reflection. (23, author's translation) premise of an unsolved murder from the 30s (a woman and her lover killing her husband), causes first Maddie, and then David, to dream of themselves as the wife and lover in the story. Each is convinced that it is the opposite gender that is at fault, and as a result, in a Rashomon-type twist, we have the same story from two very different perspectives, where even hairstyle and costume differ to distinguish the perceptions of the characters. Both the episode title and the crime itself of course pay homage to the so-called "Double Indemnity Murder" in 1927, where Ruth Snyder and her lover Judd Gray killed Ruth's husband after having him take out a life insurance policy. This was the inspiration for James M. Cain's novels The Postman Always Rings Twice (1934) and Double Indemnity (1943), both of which were famously and very successfully adapted to the screen (by Tay Garnett in 1946 and Billy Wilder in 1944, respectively). The show went to great lengths to ensure the noir aesthetics of the episode, filming only in black and white to avoid the network broadcasting a color version, and hiring Orson Wells [iconic director and star of noir classics like Touch of Evil (1958) and The Lady from Shanghai (1947)], in what would ultimately be his last onscreen appearance, to introduce the episode. Welles presents the episode as an oddity, a

giant leap backward. In this age of living color and stereophonic sound, the television show Moonlighting is daring to be different, and share with you a monochromatic, monophonic hour of entertainment. Approximately 12 minutes into tonight's episode, the image will change to black and white. Nothing is wrong with your set! I repeat: nothing is wrong with your set. Tonight's episode is an experiment, one we hope you'll enjoy, so gather the kids, the dog, grandma-and lock them in another room. And sit back and enjoy this very special episode of Moonlighting. (2.4)

This introduction was actually imposed by the network, fearing panicked viewers, but the language is evocative of the aesthetic importance of these sequences-both a throwback to the past and an experiment unique in "this age of living color", one sanctioned by a legendary figure from the silver screen. Clearly the series targets a knowledgeable viewer, one well versed in film history, who can recognize the generic allusions implicit in the episode title and associate the show with the actor famous for The Third Man (1949).

The episode proper reinforces this link with the past, setting the scene in a dilapidated nightclub (the scene of the unsolved murder) once famous among Hollywood's 
brightest stars ("they say that Judy Garland had her first kiss, her first date here!"), but now unable to find a buyer ("available for sale or lease, weddings, bar mitzvahs, and gatherings of all types!"), suggesting that the story to be told is only accessible through dreams (and dream sequences). The specificity of the allusions goes even further: as creator Glenn Gordon Caron notes, the two black and white sequences are meant to evoke not just two points of view for the two characters dreaming, but indeed two different forms of noir (associated with two different studios). While Maddie's dream is reminiscent of an MGM film like the Barbara Stanwyk vehicle A Woman in Jeopardy (1953), David's is more in keeping with Warner Bros.'s grittier noir films, complete with Raymond Chandleresque voiceover narration. Thus the episode insists on film literacy, eschewing any relation to the neo-noir films currently populating the silver screen ${ }^{5}$ and instead harkening back to classic noir (ironically most often available on the small screen at this time).

Fig. 4 and 5

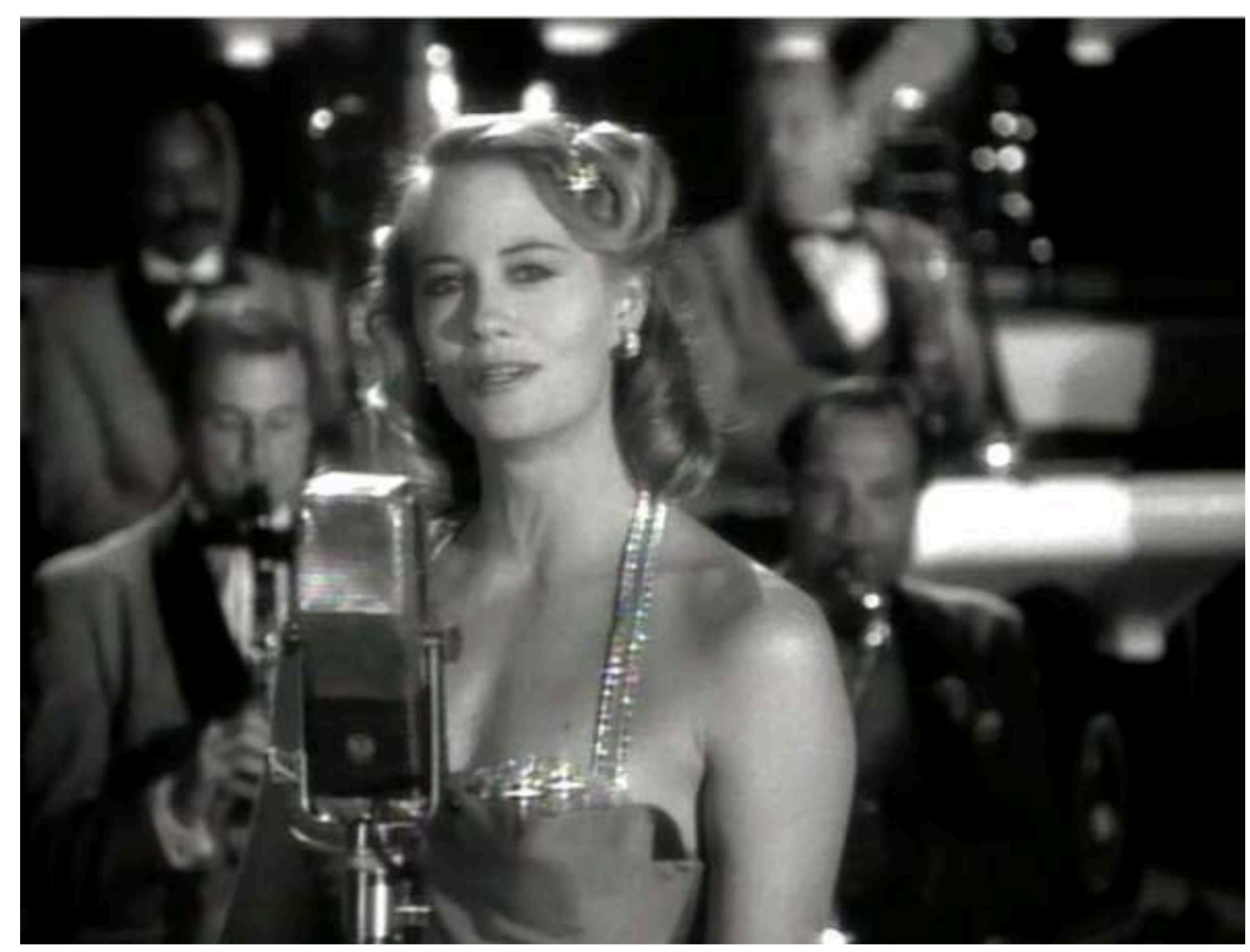




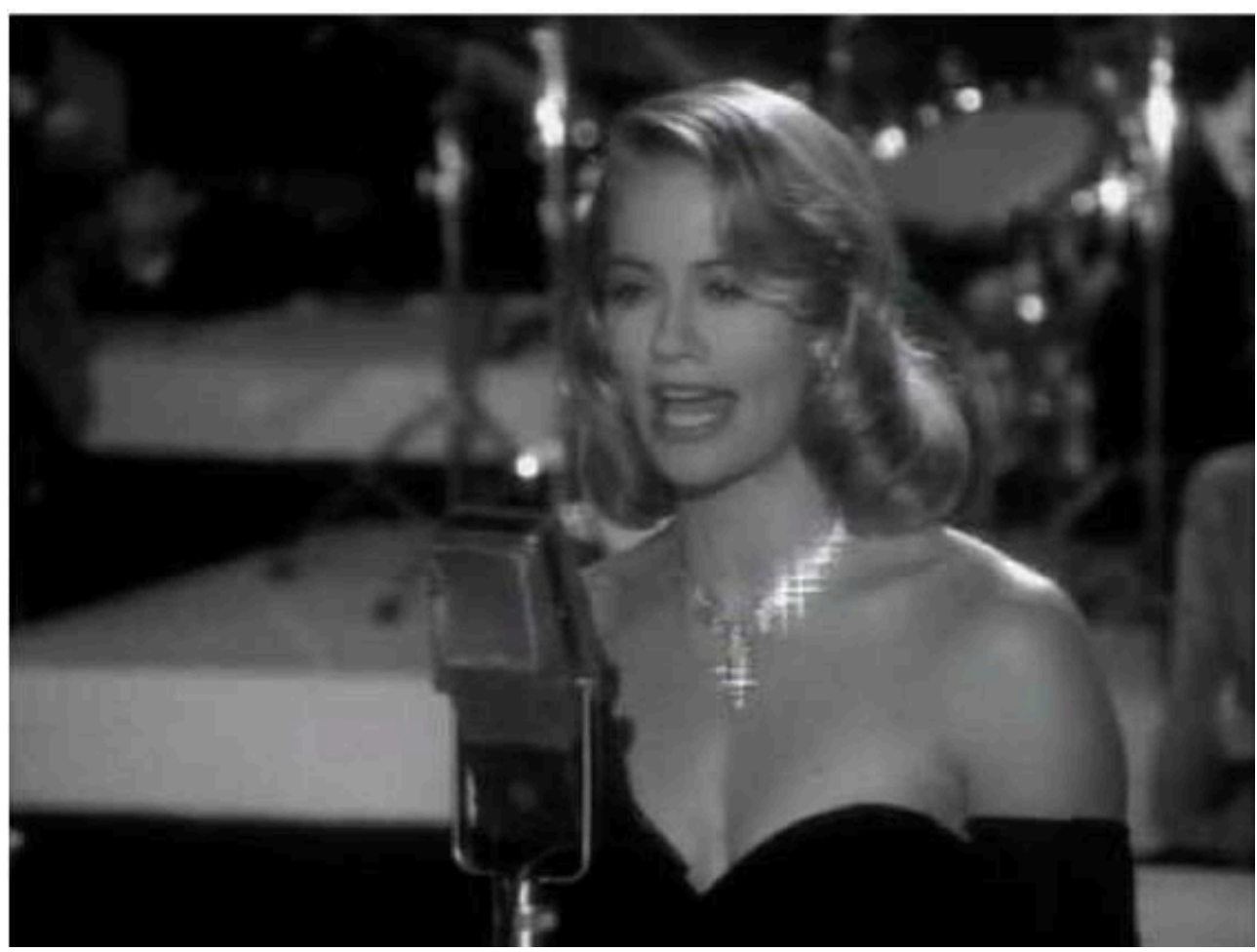

Two dream sequences, two versions of characters, story, and aesthetics (2.4) aficionado, and with the (repeated!) consummation of the "will they/won't they?" relationship that the lead characters have maintained for dozens of hours at this point in the series.

19 At the same time, the tongue-in-cheek nature of the language used in the opening moments of the episode offers up this homage as a pastiche, an element that is foregrounded in David's dream sequence, featuring Maddie's character Rita as a veritable cliché of the femme fatale in her quest to seduce a man to free her from her husband:

David/Zach sits in the window, a neon "Hotel" sign in the background blinking "HO-T", as Maddie/Rita enters in a black dress.

David/Zach (voiceover): Wow. Could she make an entrance or what? She smelled of violets, and rainy nights. What I didn't realize was, she also smelled ... of trouble. [Maddie/Rita enters, slinks towards Zach, and they immediately begin to embrace passionately as seductive music begins, and the camera zooms in on the couple while now only the letters " $\mathrm{H}-\mathrm{O}$ " are apparent in the background. The image dissolves into David/Zach smoking in the foreground as a sheet-clad Maddie/Rita drinks in bed.]

David/Zach: I don't suppose your husband knows where you are.

Maddie/Rita: He doesn't know, and he doesn't care.

David/Zach: Maybe he'd care if he knew.

Maddie/Rita: Maybe. I don't care. I don't know. You know? (2.4) 
The sequence is fairly clear in its juxtaposition of thematic continuity, stylistic pastiche, and aesthetic innovation. Here the nighttime dream sequence allows the intimacy that the daytime, workplace reality of the series prohibits, allowing the coworkers to become a couple, at least while the dream sequence holds sway. Interestingly, here as in most other dream sequences, consummation is not a happy ending, but the beginning of trouble: from David's perspective, Maddy may be "hot", but she's also a "ho", and her husband is an invisible presence in the bedroom.

Fig. 6 and 7
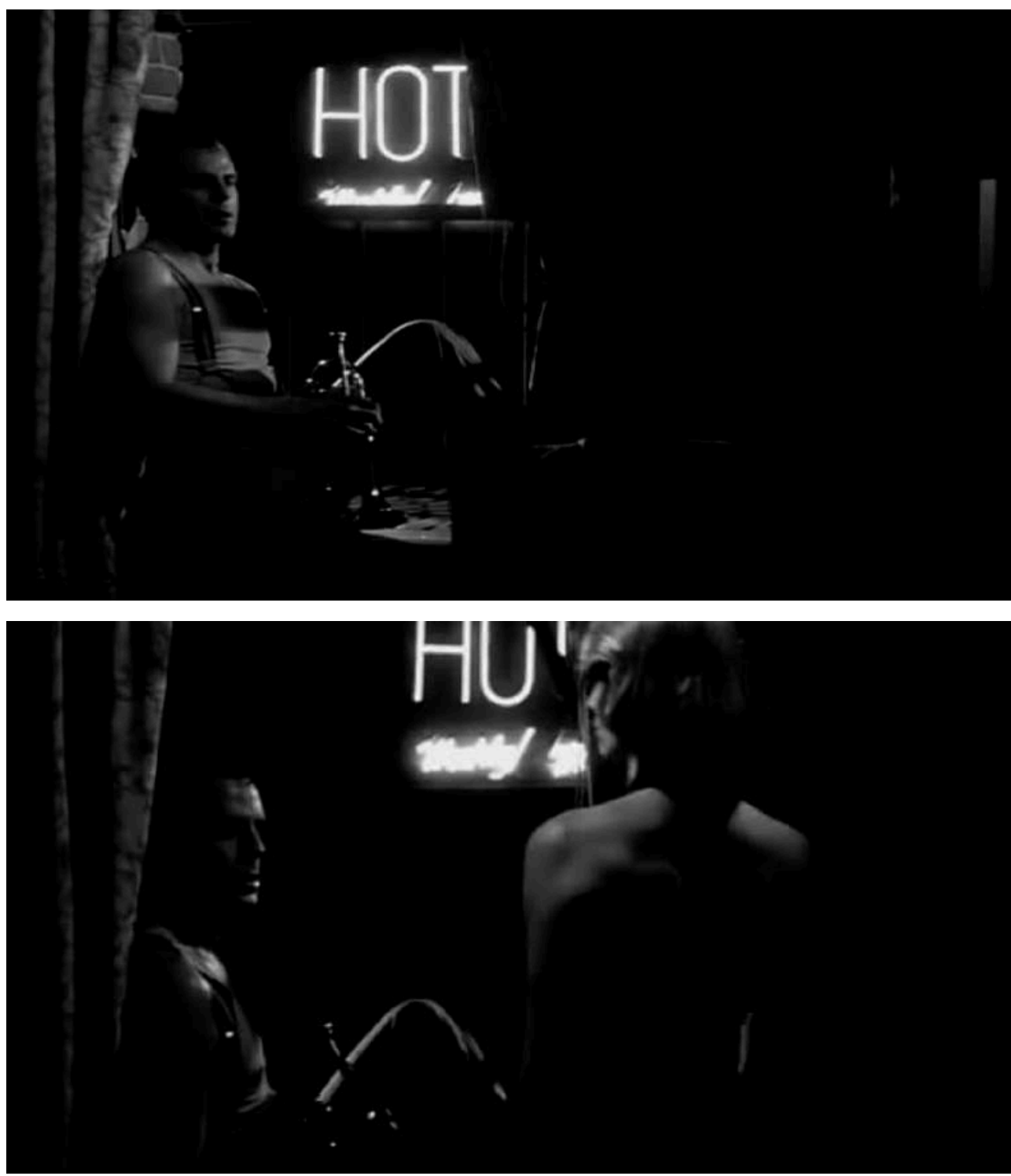

The femme fatale, seductive but dangerous..

21 The idea of perspective of course highlights the very subjective nature of not just these "he said/she said" dream sequences, but of the dream sequence in general: while David is characterized by his charismatic cool, the voiceover typical of noir offers another form of intimacy, a look into Zach's thoughts generally unavailable to viewers in the diegetic present. The suggestion that the character fears ceding control of the relationship to his romantic interest (Maddie/Rita is very much the aggressor in this 
encounter, and follows this exchange by demanding that he get her a drink ... and eventually kill her husband), gives the viewer a diegetic reason for the characters not to be together as David and Maddie in the daylight hours (other than the production's fear of changing the series' status quo).

Beyond this, however, the perspective and the aesthetics of the sequence emphasize this as a performance: of desire, of character, of genre. Choosing to stage this consummation through the generic framework of noir allows these different aspects to coalesce: by choosing dream sequences, we maintain the importance of the night, and suggest that this frees the characters from their professional obligations (both Maddie and David and their 1930s counterparts work together). Noir's famous voiceovers give an inside perspective to the tough-guy attitudes of the protagonist, and can serve as a tool to further develop characters and themes that are significant to the series; at the same time, one of the prominent themes of the genre was forbidden passion, where domestic bliss was impossible (or unattractive), and adulterous love was the norm (as we see here)-and this suggests that the relationship between these two characters, in the present or the past, is fraught with danger, and doomed to failure.

Indeed, in proper postmodern fashion, both consummation and genre are ultimately impossible to attain: after all, as Frederic Jameson reminds us, we can no longer make a noir film-among other things, now that we, unlike the makers of noir, are fully cognizant of its tropes-we can only pastiche it. And indeed, the humor of the passage is largely dependent on its exaggerated conformity to noir's generic tropes (as with the dichotomy of "hot"/"ho", or the femme fatale's empty dialogue "I don't know, you know?" in contrast to the witty commentary offered up by the "tough guy" narrator). At the same time, the overt use of tropes that are explicitly filmic and evocative of the past suggest the universal and timeless nature of male-female relations-and thus their insoluble nature. Ultimately, the murder that inspires this episode is not solved, and both characters remain convinced that their counterparts are the victims of the other's villainy.

Maddie: Thought about our little disagreement yesterday?

David: What little disagreement was that?

Maddie: The Flamingo Cove murder!

David: I didn't give it a second thought.

Maddie: Me either. Still, you get all worked up over a question neither one of us will ever be able to answer.

David: Yeah. [He gazes at Maddie through voiceover]

David (voiceover): I can answer it. She had it planned from the beginning. She set him up, just like the bartender said. Used him, and tossed him away.

[Cut to Maddie gazing at David.]

Maddie (voiceover): I know what happened. It's what always happens. He took advantage of a good woman.

[Shot-countershot of the two leads simply staring at one another as alternating voiceovers continue:] 
David (voiceover): She used him.

Maddie (voiceover): He betrayed her.

David (voiceover): She sold him down the river.

Maddie (voiceover): She loved him.

David (voiceover): He would have done anything for her.

Maddie: Well?

David: Another day, another dollar.

Maddie (grumpily): Yeah. (voiceover) Animal!

David (voiceover): Sexist! [He closes her office door.] (2.4) hours, highlighting how little the viewer normally knows of the characters' interiority. Likewise, looking at this and other dream sequences before the lead characters consummated their relationship in episode 3.14 suggests that "the Moonlighting effect" was actually built into the series itself. What the final exchange intimates is that ultimately post-feminist figure Maddie and traditional macho figure David are unable to coexist except through conflict, making gender wars the show's version of narrative conflict necessary to create story at all. Even in these moments when the series allows some form of romantic reward, that reward is accompanied by a warning of the dire consequences it entails. Thus while the use of noir makes the tragic ending to any romantic entanglements inevitable, another of the fiction's well-known dream sequences places David and Maddie in the roles of Katarina and Petruchio in The Taming of the Shrew (3.7), ostensibly allowing for a happier (though perhaps no less problematic) ending for the couple. Here however, the series insists on the caveat that the relationship is less than consensual, where the bride must literally be tied up in order to be present for the wedding, and Petruchio must be the one to bow to his wife's opinions to keep the peace. The only less problematic example of a successful relationship happens when Maddie learns that David has been married before (3.6), and a long dance sequence (choreographed by Stanley Donen of Singing in the Rain fame) plays out his failed relationship before Maddy appears to soothe his broken heart-only to immediately wake up as soon as the kissing begins.

However, this most famous dream sequence episode, "The Dream Sequence Always Rings Twice", might more profitably be examined in relation to a later episode after the lead couple consummate their relationship, and the dreaded "Moonlighting effect" is in play. The similarities between the two episodes suggest that in these dream sequences, the series explicitly remakes not just the films to which it alludes, but indeed its own previous episode. Entitled "Here's Living with You, Kid" (4.13), the later episode similarly includes two dream sequences remaking well-known films in order to comment on the romantic relationship between two of the show's characters-but here the relationship is that of the two principal secondary characters, Herbert (Curtis Armstrong) and Agnes (Allyce Beasley), who are currently in a successful relationship (in stark contrast to David and Maddie, who are estranged after she fled to another city,

Miranda, 20 | 2020 
became pregnant, and married someone else). This is the sole episode of the series in which neither of the protagonists appears; instead, the show focuses on Herbert's insecurities, as he asks Agnes to move in with him, and panics when she hesitates. Unable to sleep, Herbert's late-night viewing of classic cinema becomes a commentary on his fears about their relationship. The dream sequences here make the implicit link to film explicit, where Herbert essentially inserts himself and his beloved into the classic films playing on his television screen. Like the previous episode, the show eschews color to mimic the black and white of classical Hollywood cinema, but here the inability to express oneself that afflicts Maddie/Rita's version of the femme fatale is heightened, as the sequence uses the intertitles of silent cinema, in a call back to Rudolph Valentino's blockbuster hit The Sheik in 1921. It's a tale that has aged very badly, of a woman kidnapped by the titular sheik, Ahmed Ben Hassan, as a plaything, but who eventually grows to love her; she initially resists when he tries to force himself on her, but in the course of the story eventually yields to his seduction after he saves her from someone even worse (and she discovers that his parents were actually European...). The film was an enormous success, responsible not just for Valentino's burgeoning career, but for a veritable flood of Orientalist tales of exotic men forcing virtuous women to succumb to their charms, both in film and written fictions. Here the racist nature of the 1921 film is played for comic effect, and the repulsion/attraction of the female lead for the titular sheik becomes a more straightforward rejection of an unattractive suitor: Bert's stereotypical sheik regalia includes a veil over the bottom half of his face, more commonly seen in female Orientalist costumes. When he reveals himself as "Prince Ally Ahmed" and does away with the veil hiding his face, Agnes's shock and her attempts to dissuade him from his seduction couches her refusal in equally stereotypical terms ... of the spouse giving excuses to avoid coitus: "Do you have an aspirin? [...] I really have a splitting headache ... plus I still have this awful sunburn on my back... I think it will blister and probably peel... my lips are chapped... I feel achy all over... I must have a terrible allergy to camels" (4.13) 
Fig. 8

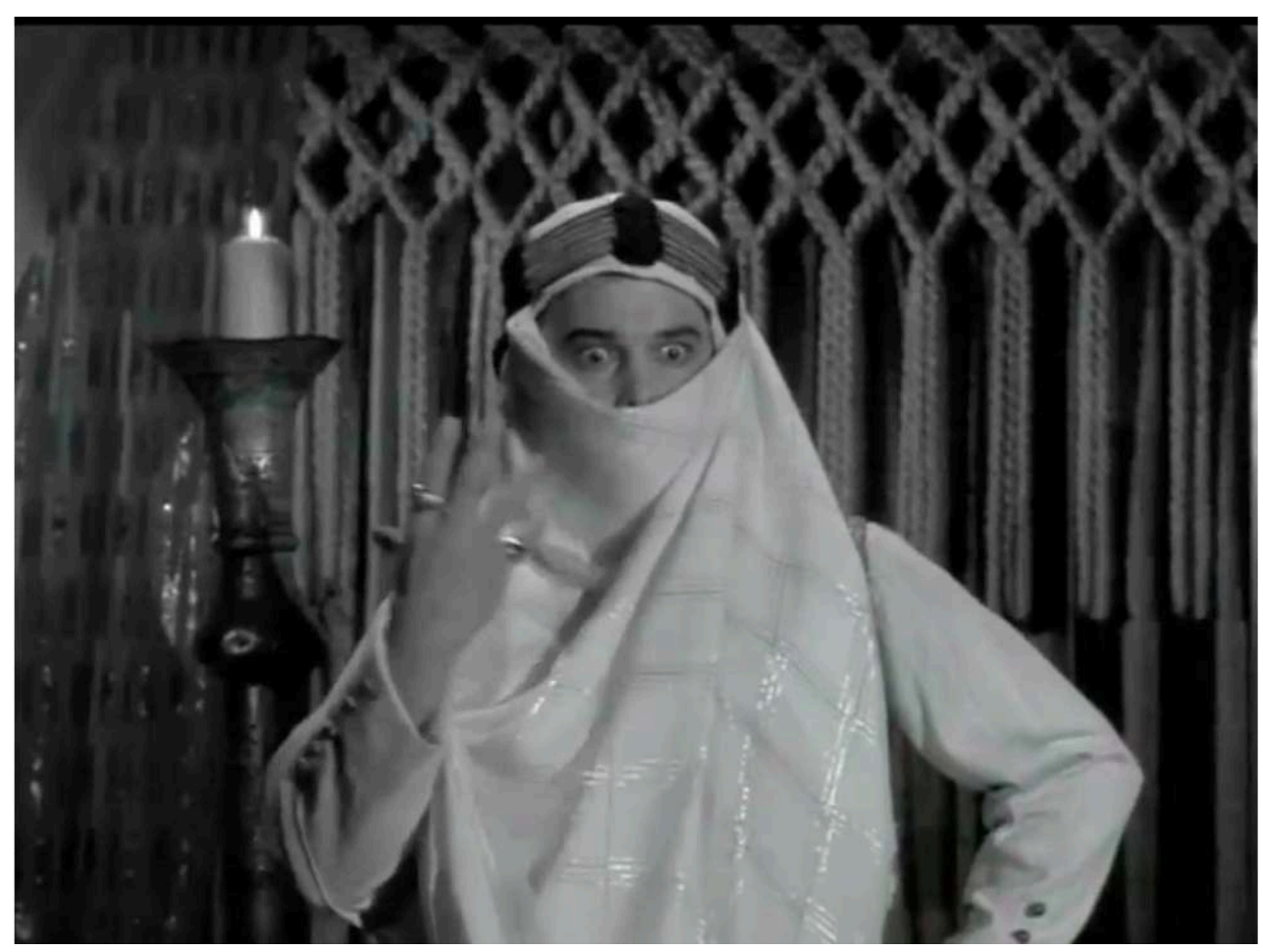

Mixing (Orientalist) gender tropes

26 The enticement of the Valentino role is of course already more difficult for a contemporary viewer to perceive given the very problematic depictions of race and gender in the film, and this depiction of an iconic romance is further deflated both by the "old-timey" dramatic piano music and the exaggerated mannerisms characteristic of silent film. The viewer has already witnessed the more "realistic" depiction of a successful relationship between these two characters in the daylight hours, and the film traditions are no longer escapist, allowing the viewer to experience a heightened fantasy version of the lead couple, but instead a mannered, problematic version our secondary characters, where the very lack of consummation has become part of the joke. The sultry nature of the noir sequence here becomes overly dramatic and willfully artificial.

The episode returns to the present just long enough for Herbert to find another channel showing old films late at night before a new dream sequence ensues, this time as Casablanca. The series once again willfully contradicts one of the most famous romances in film history, offering up an Elsa that is more than willing to leave Rick behind in Moonlighting's version of the farewell scene:

Agnes/Elsa: Bert-

Herbert/Rick: Agnes, there's a time for talking and a time for listening, and the way I see it, it's time for me to do the talking for both of us. What we feel, what we need, none of that matters anymore. Maybe someday you'll understand that the problems of three little people don't amount to a hill of beans in this crazy world. Maybe someday I'll understand why I always talk like that. But for now ... [he reaches over to touch her face] Here's looking at you, kid.

Agnes/Elsa [puzzled]: Here's looking at me? What does that mean, here's looking at 
me?

Herbert/Rick: Never mind. I'm just telling you, we've got to put aside our own desires, our own needs, and you've got to do the right thing, you've got to get on that plane, where you belong.

Agnes/Elsa: Of course I'm getting on that plane! It's leaving any minute. Besides, Victor's on board-where else would I go? [cut to Herbert, looking crestfallen, then back to Agnes, who realizes what he suggesting:] Ohhh. You thought ... you and I... [She begins to laugh.] (4.13)

In many ways the two episodes show themselves to be diametrically opposed: while the earlier noir episode sought to maintain or even heighten the tension between the two beautiful leads, the later episode seeks to deflate any hint of romance between the less conventionally attractive secondary characters; while the earlier sequences opposed the daylight relationship between David and Maddie with the wish fulfillment of the night's dreams, Herbert's fears for his relationship stem in part from his job interfering with his private life (he's been on nightly stakeouts for weeks). The later episode has moved from pastiche to overt parody, but the source of the parody is as much Moonlighting as these classic films.

At the same time, "Here's Living with You, Kid" also changes the nature of that universal timeless and insoluble romance. Whereas "The Dream Sequence Always Rings Twice" insists on the transgressive nature of the noir past, allowing the characters the freedom to act on desires that are taboo in the light of day, "Here's Living with You, Kid" suggests that on the contrary, these past ideals of masculinity are anathema to a successful relationship, and constrain Herbert rather than freeing him. By insisting on their framework (in the carefully placed shots of television set, introductory title card, and presenter introducing the films), and showing their distance from the characterization of Herbert, making him an absurd version of famous romantic leads Valentino or Bogart, the episode suggests that these role models are indeed no longer transgressions, but types that may destroy the romance they are intended to inspire. Thus the rest of the episode shows Agnes agree to move in, but only once Herbert abandons these dated stereotypes of male virility. In the light of day, he first feigns disinterest, in keeping with his dream roles, and when Agnes leaves indignantly, he ultimately prostrates himself before her, professing his love, and being rewarded accordingly. The switch from general pastiche of noir to specific adaptations of The Sheik or Casablanca, from dialogue between the episodes' two sequences to repetition of a single character's voice (and insecurity), and from romantic tension to romantic deflation, ultimately resolves the question of will they/won't they-but the absence of the main characters suggests that their own strictly held gender norms, as seen in the noir dream sequences, extinguish any hope for a relationship: in an episode a few weeks before (4.10), Maddy has a dream sequence contrasting a fatherly David, who dons an eye mask at 8:30 sharp (played by iconic "good guy" Pat Boone), with "bad boy" David, a creature of the night (and object of Maddie's reluctant desire). To our successful modern couple Herbert and Agnes, these past models literally make no sense ("Here's looking at me? What does that mean?"); however, as its name indicates, the relationship between Maddie and David ultimately belongs to the moonlight, and will not survive the light of day. 


\section{Conclusion}

Perhaps the same can be said for the series as a whole-by structuring the show around an explosive relationship, by relying on postmodernism and pastiche to the detriment of plot (Jameson could have effectively used this series as an example in his critique of postmodernism), the show was hard pressed to maintain itself in the endless present that characterizes American television. Though the series was of course more than the binary before/after shown here, the comparison of these two episodes and their dream sequences allows for a better understanding both of the fiction's dominant characteristics, and the innately brilliant (but flawed) nature of its premise. Nonetheless, as one of the first truly literate and openly metafictional television shows, joyfully multiplying its references and inside jokes, Moonlighting ushered in a new understanding of what television was and could be-and for that, television scholars and viewers can only be profoundly grateful.

\section{BIBLIOGRAPHY}

Blood Simple, dirs. Joel and Ethan Coen, Circle Films, 1984.

Body Double, dir. Brian De Palma, Columbia Pictures, 1984.

Body Heat, dir. Lawrence Kasdan, Warner Bros., 1981.

Bronfen, Elisabeth. Night Passages: Philosophy, Literature, and Film (2008). New York: Columbia University Press, 2013.

Bringing Up Baby, dir. Howard Hawkes, RKO Radio Pictures, 1938.

Burkhead, Cynthia. Dreams in American Television Narratives: From Dallas to Buffy. New York: Bloomsbury Academic, 2013.

Cain, James M. Double Indemnity (1936). London: Orion, 2005.

---. The Postman always Rings Twice (1934). New York: Knopf Doubleday, 2010.

Casablanca, dir. Michael Curtiz, Warner Bros., 1942.

Cheers, NBC, 1982-1993.

Double Indemnity, dir. Billy Wilder, Paramount, 1944.

Friends, NBC, 1994-2004.

“Glenn Gordon Caron”. Television Academy Foundation. May 31, 2019. https://

interviews.televisionacademy.com/interviews/glenn-gordon-caron

Hammett, Dashiel. The Thin Man (1934). London: Vintage, 1989.

Hatchuel, Sarah. Rêves et séries américaines: La fabrique d'autres mondes. Aix-en-Provence: Rouge profond, 2015.

Hill Street Blues, NBC, 1981-1987. 
Horowitz, Joy. “The Madcap behind Moonlighting.” The New York Times. March 30 1986. https:// www.nytimes.com/1986/03/30/magazine/the-madcap-behind-moonlighting.html Jameson, Frederic. "Postmodernism and the Consumer Society." The Cultural Turn: Selected Writings on the Postmodern, 1983-1998. London: Verso, 1998.

L.A. Law, NBC, 1986-1994.

The Lady from Shanghai, dir. Orson Welles, Columbia Pictures, 1947.

The Life of an American Fireman, dir. Edwin S. Porter, Edison Studios, 1903.

The Office, NBC, 2005-2013.

Paskin, Willa. "Celebrating the brilliance of Moonlighting." Salon March 9 2013. https:// www.salon.com/2013/03/09/rewind_celebrating_the_brilliance_of_moonlighting/

The Philadelphia Story, dir. George Cukor, MGM, 1940.

The Postman Always Rings Twice, dir. Tay Garnett, MGM, 1946.

The Postman Always Rings Twice, dir. Bob Rafelson, Paramount, 1981.

Rashomon, dir. Akira Kurosawa, Daiei Films, 1950.

St. Elsewhere, NBC, 1982-1988.

Sherlock Junior, dir. Buster Keaton, Metro-Goldwyn Pictures, 1924.

The Sheik, dir. George Melford, Paramount, 1921.

Singing in the Rain, dirs. Stanley Donen, Gene Kelly, MGM, 1952.

The Thin Man, dir. W.S. Van Dyke, MGM, 1934.

The Third Man, dir. Carol Reed, London Films, 1949.

Touch of Evil, dir. Orson Welles, Universal Pictures, 1958

Thompson, Robert J. Television's Second Golden Age: From Hill Street Blues to ER. NY: Continuum Publishing, 1996.

Walters, James. Alternative Worlds in Hollywood Cinema: Resonance Between Realms. Bristol: Intellect, 2008.

Williams, JP. "The Mystique of Moonlighting: 'When You Care Enough to Watch the Very Best."' The Journal of Popular Film and Television, Vol. 16, $\mathrm{n}^{\circ} 3,1988,90-100$.

A Woman in Jeopardy, dir. John Sturges, MGM, 1953.

X-Files, Fox, 1993-2018.

\section{NOTES}

1. Thompson posits that the first days of television in the 1950s represented a first Golden Age, creating many of the forms and traditions that are still adhered to some 70 years later (sitcoms with bright lighting, multiple cameras, and a live studio audience, game and variety shows, etc.), while the 1980s developed a new and more complex form of television drama, with more complex characters, ongoing storylines, and heightened realism (series like St. Elsewhere, Hill Street Blues, LA Law). 
2. "Will they/won't they?" has become a well-used trope in television, from Ross and Rachel in Friends to Mulder and Scully on X-Files or Jim and Pam on The Office. Because of "The Moonlighting effect", the answer was often that "they won't", though this has slowly changed since then (as these examples demonstrate).

3. Various oral histories (Paskin, Horowitz, Caron) catalog the show's many production problems, from writers' delays in producing scripts to difficult relations between the two leads (and the production staff).

4. "The Dream Sequence Always Rings Twice" (2.4), "Big Man on Mulberry Street" (3.6), "Atomic Shakespeare" (3.7), "It's a Wonderful Job" (3.8), "A Trip to the Moon" (4.1), "Come Back Little Shiksa” (4.2), “Tracks of My Tears" (4.10), "Here's Living with You, Kid” (4.13), “A Womb with a View" (5.1), "I See England, I See France, I See Maddie's Netherworld" (5.7).

5. Films like Blood Simple (1984), Body Heat (1981), Body Double (1984), or the remake of The Postman Always Rings Twice (1981).

\section{ABSTRACTS}

The 1980s series Moonlighting was one of the first dramedies on the small screen; it took its cue from venerable genres like the screwball comedy or the hard-boiled novel (particularly The Thin Man) and translated them to television's changing structures and aesthetics, participating in what has been termed the second Golden Age of television. However, the Nick and Norah Charles of Moonlighting, David and Maddie, were not married: on the contrary, the series was largely fuelled by the tension between the two leads, who were constantly sparring but were seemingly drawn to one another. Though this romantic tension has long been a staple of the silver screen, translating it into weekly episodes was more complicated-like its sitcom counterpart Cheers, also airing at the time, the writers struggled to maintain the central tension without creating undue frustration for the viewer. Moonlighting chose a particularly novel solution: the dream sequence. While David and Maddie continued to spar in "real/reel" life, the series offered regular dream sequences where they consummated their relationship either as themselves or as others. These dream sequences allowed for aesthetic and narrative innovation while maintaining thematic continuity: David and Maddie appear in dance sequences, in film noir, in The Taming of the Shrew, where they become the couple that the series keeps postponing. More than consummation, then, the series offers the performance of that consummation, voluntarily coded in different genres and styles, to the extent that the brief period where the two characters were a couple within the diegesis was met with general disappointment from fans and creators alike. This article explores the way that the series plays with genre, style, and viewer expectations in these different dream sequences.

La séries Moonlighting était une des premières séries de "dramedy" à paraître sur le petit écran, une fiction inspirée par le screwball comedy et le roman noir (hard-boiled novel), et qui transposait ces influences au cadre des structures et esthétiques télévisuelles. De ce fait, Moonlighting participait pleinement à l'évolution du média et de ce qu'on appelle le deuxième âge d'or de la télévision. Le rapport conflictuel entre les deux protagonistes constituait une trame majeure de la série. Alors que cette tension romantique a longtemps été habituelle sur le grand écran, traduire ce trope en un récit sériel était bien plus compliqué pour les scénaristes, qui cherchaient un équilibre entre suspense dans le récit et frustration du spectateur. Moonlighting a choisi une 
solution plutôt novatrice : la séquence de rêve. Alors que les querelles des protagonistes David et Maddie continuaient en journée, la série offraient des séquences de rêve nocturnes qui permettaient au couple d'avoir la relation amoureuse que les spectateurs attendaient. Ces séquences étaient un lieu d'innovations esthétiques et narratives tout en gardant une certaine continuité thématique : David et Maddie apparaissent dans des séquences de danse, dans un film noir, dans une version de La Mégère apprivoisée. Ainsi la relation amoureuse devient ouvertement performance, dans divers styles et genres-et de fait lorsque cette relation s'est établie «de jour ", le public en fut déçu. Cet article explore la façon dont la série joue avec le genre, le style, et les attentes du public dans ces différentes séquences de rêve.

INDEX

Keywords: Moonlighting, TV series, dream sequence, gender

Mots-clés: Moonlighting, série télévisée, séquences de rêve, gender

\section{AUTHORS}

\section{SHANNON WELLS-LASSAGNE}

Professeur des Universités

Université de Bourgogne Franche-Comté

Shannon.Wells-Lassagne@u-bourgogne.fr 